\title{
Exploring the Effects of Preschool Teachers' Epistemological Beliefs on Content-Based Pedagogical Conceptualizations and PCK Integrations towards Science Teaching
}

\author{
Ali Yigit Kutluca ${ }^{1 *}$ (1), Nilay Mercan 2 (1) \\ ${ }^{1}$ Department of Elementary Education, Faculty of Education, Istanbul Aydin University, Istanbul, TURKEY \\ 2 Preschool Education, Institute of Graduate Studies, Istanbul Aydin University, Istanbul, TURKEY \\ * Corresponding author: alikutluca@aydin.edu.tr
}

Received: 9 Oct. 2021 Accepted: 16 Jan. 2022

Citation: Kutluca, A. Y., \& Mercan, N. (2022). Exploring the Effects of Preschool Teachers' Epistemological Beliefs on ContentBased Pedagogical Conceptualizations and PCK Integrations towards Science Teaching. European Journal of Science and Mathematics Education, 10(2), 170-192. https://doi.org/10.30935/scimath/11661

\begin{abstract}
:
This exploratory case study aims to determine how preschool teachers' epistemological beliefs influence their pedagogical conceptualizations of science teaching. The research was conducted with a total of 10 teachers that were selected among 61 preschool teachers by their epistemological beliefs. The participants were divided into two sub-groups consisting of five persons each to represent the lower and higher epistemological profiles, based on their scores obtained from the Epistemological Belief Scale Towards Learning (EBSTL). A written form (Content Representation Task [CRT]) reflecting the content representations (CoRes) methodology was applied to determine these participants' pedagogical conceptualizations of early childhood science teaching and to reveal their PCK integration. The qualitative data collected in this way were analyzed through the constant comparative method, inductive content analysis, in-depth explicit PCK analysis, enumerative approach, and PCK mapping. The analysis results showed that preschool teachers in the higher epistemological beliefs referred more to the science literacy vision and tended to use inquiry-based teaching approaches, and they addressed science teaching in a more holistic structure. Finally, both groups of teachers were insufficient to integrate assessment and curriculum components into early childhood science teaching. The results showed that epistemological beliefs directed the early childhood science teaching practices based on science literacy vision.

Keywords: preschool teacher, epistemological beliefs, early science teaching, pedagogical conceptualizations
\end{abstract}

\section{INTRODUCTION}

Children have an innate orientation towards learning, gaining experience, and discovering (Gopnik, 2012). This orientation not only supports the beginning of children's learning desires at an early age but also allows them to continue throughout life (Worth, 2010). Expanding educational researches and curricula in the context of early childhood science education have highlighted that the early years are of critical importance in science literacy education, which begins in early childhood, and continues and deepens throughout life (e.g., Bybee, 2013; National Research Council, 2012). Given that children have the potential to wonder, research, and question the environment in which they live, effective science experiences at an early age can encourage them to understand scientific concepts and develop scientific thinking skills (Trundle \& Sackes, 2015). Moreover, the children experiencing the science practices at an early age will be more likely to have a positive attitude towards science (Broström, 2015). Transformation of these curiosities and desires of children into a scientific thought is possible with qualified early science teaching (Nayfeld et al., 2011). To achieve this, preschool teachers' pedagogical competencies and particularly their awareness of the child's cognition are significant (Gerde et al., 2018). 
In terms of early childhood science teaching, the role and impact of the teacher take on a more critical meaning. Teachers' knowledge levels and pedagogical competencies in science are some of the major predictors of supporting children's sense of wonder for science (Barenthien et al., 2020). What is mainly expected from preschool teachers is that they perform science teaching based on inquiry-based activities involving game-based and child-centered pedagogical strategies (Larimore, 2020). It is the task of teachers to encourage children to ask questions by means of enhanced science activities allowing children to be engaged in science and conduct research (Toyama, 2016). The main problem here is that teachers prefer one-way communication in most activities and tend to teach concepts directly (Hamel et al., 2021). This shows that preschool teachers cannot integrate content and pedagogy well and adopt a teacher-centered approach in science teaching. Current research findings have revealed that preschool teachers spare less time to science teaching than other teaching activities and tend to push them into the background (e.g., Piasta et al., 2014; Sundberg \& Ottander, 2013). This is thought to be due to teachers' lack of subject matter knowledge, pedagogical content knowledge, and personal, educational trajectories or teaching experience (Nilsson, 2015; Oppermann et al., 2019). Although it is put forward by the early science childhood education literature that epistemological and pedagogical orientations and pedagogical content knowledge (PCK) (Andersson \& Gullberg, 2014; Wu et al., 2021) are interrelated, it has been quite limited studies in discovering how epistemological beliefs influence teachers' PCKs.

For this reason, this study revealed the preschool teachers' pedagogical conceptualizations of science teaching based on their epistemological profiles. Consequently, study aims to determine how preschool teachers' epistemological beliefs influence their pedagogical conceptualizations of science teaching. The main hypothesis within this aim is that preschool teachers with higher epistemological beliefs will have pedagogical conceptualizations that are more child-centered and more suitable for science literacy vision.

\section{THEORETICAL BACKGROUND}

\section{The Role of Teachers in Early Science Education}

Many educational standards and curricula have the same view that science literacy is a target definitely required to be followed by all individuals from early childhood to 12th grade-students (MoNE, 2013; New Generation Science Standards, 2013; National Research Council, 2012). Accordingly, science literacy represents children's ability to relate science and its processes to everyday contexts (Smolkin \& Donovan, 2015). This target can be achieved only when children meet science and its exploratory practices early (Bauer \& Booth, 2019; Broström, 2015). The qualified understanding of science and scientific reasoning skills that are acquired in early childhood serve as an important pioneer for the children's academic achievements in their future educational lives (Morgan et al., 2016; Sackes et al., 2010). The fact that especially early childhood science teaching is enriched with game-based, inquirybased, and child-centered activities will help children achieve the science literacy vision. Thanks to the early childhood science teaching performed in this way, children will have a qualified understanding of science to establish the conceptual basis to be used in the future academic period (Bell \& Clair, 2015). However, it is not sufficient just to provide appropriate curriculum materials for such science teaching. Qualified science teaching can be achieved with preschool teachers who combine the content and pedagogy with the appropriate curriculum materials and have high pedagogical content knowledge (Larimore, 2020; Neuman \& Danielson, 2021). Therefore, while planning and performing the science teaching, preschool teachers must have many resources such as PCK, subject matter knowledge, and pedagogical orientations and consider these resources (Gropen et al., 2017; Oppermann et al., 2019). In this way, teachers will not only structure the science teaching activities based on direct knowledge transfer or concept teaching, but they will also ensure children's participation in informal activities such as yogurt making, nutrition and hence support their acquisition of scientific process skills (Charlesworth \& Lind, 2010). This is possible only when preschool teachers structure the science teaching activities to 
be integrated with the game-based, inquiry-based and child-centered strategies that will support children's cognitive action.

\section{Epistemological Beliefs and Pedagogical Content Knowledge in Early Science Teaching}

The fundamental aim of early childhood science teaching is to help children have a qualified understanding of science. To achieve this, it is important that preschool teachers are aware of how children internalize and form scientific knowledge. The existing research has the same view that there is a deep connection between beliefs and practices, especially in preschool educational environments (e.g., Merino et al., 2014; Tanase \& Wang, 2010). Characterized as the series of fundamental beliefs about knowledge and knowing, the epistemological beliefs can also be conceptualized as the system of more or less independent and multi-dimensional beliefs that can be developed asynchronously (Chen, 2012). Tsai et al. (2011) suggest that epistemological beliefs involve four dimensions, including certainty of knowledge, simplicity of knowledge, source of knowledge, and justification of knowledge. The first two dimensions refer to the nature of knowledge, while the other two are rather related to the nature of knowing (Liang \& Tsai, 2010).

Epistemological beliefs are generalizable in a certain domain and domain-specific (Ho \& Liang, 2015). Accordingly, it can be suggested that teachers' epistemological beliefs specific to any domain positively or negatively impact the teaching practices (Mansour, 2013). These beliefs of teachers in their teaching and pedagogical capacity are also related to their teaching knowledge and experience (Brown, 2011). Teachers' epistemological beliefs may act as an amplifier, filter, or guide when planning and implementing instruction (Gess-Newsome, 2015). Because their professional knowledge is complex and dynamic, they tend to be influenced by their epistemological beliefs focusing on the nature of knowledge and knowing (Hand et al., 2018). Research suggested that teachers with higher epistemological beliefs have a richer repertoire of teaching strategies, focus more on students' conceptual changes, and can better identify students' conceptual difficulties (Hashweh, 1996; Tanase \& Wang, 2010).

On the other hand, claiming that epistemological beliefs are related to teaching actions, Sengul et al. (2020) have determined that teachers with higher epistemological beliefs focus on cooperative teaching activities by focusing on multiple perspectives in their classrooms. Considering in terms of early childhood education, epistemological beliefs become much more important. Brownlee (2001) puts forward that the relativity of early childhood teachers' beliefs is associated with the depth and metacognitive reflections of the teacher. The preschool teachers believing that knowledge is uncertain may be more likely to integrate the teaching activities with other contexts. In addition, it can be thought that these teachers tend to follow a roadmap based on power-sharing in the classroom (Brownlee et al., 2011).

As mentioned, teachers use both their teaching knowledge and beliefs to what extent they can realize it while organizing their classroom activities to achieve certain teaching targets (Pajares, 1992). When teachers believe that they can apply their teaching knowledge effectively, they will be more likely to realize it in real classrooms (Park \& Chen, 2012). Accordingly, their pedagogical conceptualization related to any subject makes the bridge between their teaching beliefs and teaching knowledge more visible (Alexander, 2004). In other words, it can be thought that teachers reflect insights about their PCK through their pedagogical conceptualizations. Here, it can be thought that pedagogical conceptualizations concern belief, efficacy, and knowledge related to teaching and teachers' actions in the classroom (Hashweh, 2013; Prachagool et al., 2016). Therefore, teachers' pedagogical conceptualizations, including all of their knowledge, beliefs, and attitudes, affect their ability to construct knowledge effectively with children and their pedagogical decisions (Hedges \& Cullen, 2005).

As can be seen, the beliefs about learning and teaching are not sufficient by themselves in real classrooms (Appleton, 2006). In addition, teachers also need to bring their own teaching knowledge into action. Teacher knowledge is one of the most significant factors that influence teachers' behaviors in the classroom and the success of their students (Gess-Newsome, 2015). But teacher knowledge does not 
consist of only subject matter knowledge (Shulman, 1986). Grossman (1990) collected the types of knowledge a teacher should have for effective teaching under four groups: subject matter knowledge, general pedagogical knowledge, PCK, and knowledge of context. According to many researchers on teacher education, pedagogical content knowledge, which is the most important teacher knowledge domain representing qualified teaching, is nourished by teachers' other content knowledge (e.g., Magnusson et al., 1999; Park \& Chen, 2012).

On the other hand, especially when considered in terms of early childhood education context, it has been claimed that the teacher's love for his/her profession and students, his sacrifices, his psychological characteristics, being suitable for practicing the teaching profession, serve as the cement in acquiring PCK components (Duran et al., 2021). According to Shulman's (1986) original definition, PCK refers to the most useful presentations, the strongest analogies, and the best examples and explanations used for making a particular topic comprehensible by others. Therefore, PCK includes all teacher and subject matter-specific knowledge and skills that develop via teaching experiences over time (Kind, 2009). Magnusson et al. (1999) put forward that the subject matter knowledge, pedagogical knowledge, and knowledge of context, included in Grossman's (1990) model of teacher knowledge, have a strong mutual influence on PCK, and that PCK consists of five components.

These components are detailed below:

- Orientations to teaching science (OTS): This component represents teachers' beliefs about goals and objectives for teaching science at different grade levels. In addition, it acts as an important amplifier and filter that mediates teachers to reflect their subject-specific professional knowledge into classroom practice (Gess-Newsome, 2015).

- Knowledge about 'students' understanding (KSU): This component represents teachers 'conceptualization of their students' misconceptions, learning difficulties, motivations, and prior knowledge about a particular topic. KSU shows that the teachers care about developing their students' scientific knowledge.

- Knowledge about science curriculum (KSC): This component expresses teachers' knowledge about the curriculum available to teach a particular subject (Grossman, 1990). KSC enables the teacher to establish more coherent relationships between the subject context and general and specific objectives.

- Knowledge about instructional strategies (KISR): This component represents teachers' discipline-specific strategies and subject-specific (activities and representations) strategies during teaching. Accordingly, teachers need to integrate general strategies and techniques into the subject area they teach.

- Knowledge about assessment of science learning (KAs): This component includes the dimensions that are important for evaluation and the teacher's knowledge about the methods to be used during evaluation. For this, teachers need to know well what and how to evaluate.

PCK is not only subject-specific but also consists of a dynamic structure that sees knowledge as a part of the action (Gess-Newsome et al., 2019). On the other hand, it depends not only on which components are required for a subject but also on how and to what extent these components interact with each other (Abell, 2008). The more relationships a teacher has between PCK components, the stronger the interaction between related components. Therefore, the level of interactions between these five PCK components reflects qualified teaching. In other words, the balanced and consistent interaction of all components with each other is an indicator of quality teaching (Park, 2019). Taking this significance into account, Park and Oliver (2008) proposed a pentagon model to show the potential progress of any of these five components. According to the researchers, the knowledge interactions before and after teaching determine the structure of PCK. 
As in many areas, PCK is important in early childhood science teaching, but it is not sufficient alone. Early childhood educators have argued that curriculum and learning areas should be integrated through child-centered epistemologies (Gunn et al., 2021; Karabon, 2021). But the immediate and unwritten nature of learning in early childhood education has complicated this further. To overcome this, early childhood science teachers should internalize and integrate content and pedagogy well (Barenthien \& Dunekacke, 2021; Graue et al., 2015). Barenthien et al. (2020) suggest that PCK for early childhood science teaching is a product of teachers' content-based conceptualizations and pedagogical strategies. For this reason, preschool teachers need to integrate content, pedagogy, and teaching contexts with appropriate curriculum materials to improve their science-specific PCKs.

\section{The Context of This Study}

The fundamental nature of this study is to reveal how epistemological beliefs about learning and teaching influence the pedagogical conceptualizations of early childhood science teaching. As stated before, preschool teachers with higher epistemological beliefs and PCKs are needed for qualified early childhood science teaching (e.g., Gropen et al., 2017; Neuman \& Danielson, 2021). Based on this perspective, it is considered important to describe how preschool teachers integrate their current epistemological orientations into their science teaching activities for qualified early childhood education.

Early childhood education is not compulsory in Turkey and has covered children's education aged 3-6. The latest version of the National Early Childhood Program was developed in 2013 to improve the quality of education for young children at the early childhood level. The Turkish preschool curriculum allows preschool teachers to do creative and original activities for young children. In addition, it focuses on five developmental areas with a holistic approach. These areas are social and emotional, motor, cognitive, and language development areas and self-care skills (MoNE, 2013). The main purpose of the program, in which learning by discovery is handled as a priority, is not to teach the subject, but to bring learning outcomes to children with the help of that subject.

For this reason, themes or topics are a means, not an end. According to Sackes (2014), Turkish preschool teachers' beliefs about early science teaching align with the Developmentally Appropriate Practices of the National Association for the Education of Young Children (NAEYC). Therefore, preschool teachers are expected to use child-centered and play-based pedagogical strategies when planning and implementing early science teaching (Larimore, 2020). In this way, preschool teachers need to ask children qualified questions and help them acquire scientific process skills such as observation and prediction (MoNE, 2013). Unfortunately, Turkish preschool teachers have allocated very little time to science activities in their classrooms, although they claim they are competent in early science teaching (Erden \& Sonmez, 2011; Ozbey \& Alisinanoglu, 2008, Saglam \& Aral, 2015). It can be thought that this is due to their low level of subject matter knowledge and pedagogical content knowledge (Aydin \& Guney, 2017; Sackes et al., 2012).

There are studies, in the literature that have been conducted in the context of early science education and with the preschool teachers and teacher candidates. The main topics focused on by these studies generally include self-efficacy (Opperman et al., 2019), beliefs and attitudes towards science (Merino et al., 2014), PCK, and pedagogical competencies (Gropen et al., 2017; Neuman \& Danielson, 2021), views on curriculum and strategies (Arias et al., 2016; Pierro, 2019), and science teaching experiences (Thulin \& Redfors, 2017). According to the agreed view in the studies, the preschool teachers and teacher candidates have positive attitudes and beliefs about science teaching. However, preschool teachers are inadequate and in a dilemma in integrating mentioned pedagogical tools into science teaching. On the other hand, there are also studies in the literature in which epistemological beliefs are evaluated in the context of preschool teacher education. These studies have concluded that professional identity differentiates personal epistemologies (e.g., Brownlee et al., 2008; Tanase \& Wang, 2010). 
As can be seen, science teaching and epistemological beliefs are not new contexts for the early childhood education literature. Theoretical and empirical evidence has shown that science teaching, and epistemological beliefs are issues to consider for early childhood education. It has also been suggested that these two contexts are interrelated (e.g., Arias et al., 2016; Brownlee et al., 2011; Larimore, 2020). Unfortunately, it has not been studied much how these two contexts affect each other in a pedagogical sense in the literature of preschool teachers and early science education. Existing studies have been carried out from a quantitative point of view in general (Ugras \& Cil, 2016; Wu et al., 2021).

On the other hand, many researchers have tried to understand how the individual PCK components of especially science and elementary teachers develop and how this development can be supported (Chan \& Hume, 2019; Kutluca, 2021a). However, limited studies have investigated the interrelationships between components in understanding the construction of PCK in the early science education research literature (Gropen et al., 2017; Kutluca, 2021b; Kutluca \& Nacar, 2021). Karabon (2021) suggested that the connection between preschool teachers' epistemological and practical knowledge affects their pedagogical decisions and conceptualizations. For this reason, it can be thought that all decisions about teaching are the product of professional epistemologies. This has shown that the complex relationships between early science teaching and epistemological beliefs are a phenomenon that needs to be discussed through the teacher's PCK and from a qualitative perspective (Karabon, 2021; Wu et al., 2021). Therefore, the answer to the following two research questions was sought in this study:

1. How do the epistemological beliefs of preschool teachers affect their content-based pedagogical conceptualization of science teaching?

2. How do the epistemological beliefs of preschool teachers affect the integration between PCK components for science teaching?

\section{METHOD}

This study is an exploratory case study. With this case study approach, any phenomenon and the grounds leading to this phenomenon are investigated (Merriam \& Tisdell, 2016). The reflection of teachers' epistemological beliefs on their pedagogical conceptualization of early childhood science teaching is the case discussed in this study. Even more specifically, it has been tried to reveal new knowledge emerging through the epistemological beliefs of preschool teachers who have truly experienced science teaching (Gerring, 2004).

According to Thomas (2015), the focus of the case study is to try to describe an event as it is. It is triangulation that allows a more detailed description of these cases (Denzin, 2012). Triangulation, which serves as a bridge between quantitative and qualitative epistemologies in mixed-method research, helps to consider the existing phenomenon from a more holistic perspective (Flick, 2018). In this study, the data collected from multiple data sources (epistemological belief scale, interviews) was diversified with different qualitative analysis approaches (inductive analysis, enumerative approach, PCK mapping). The steps of this methodology have been detailed in Figure 1. 


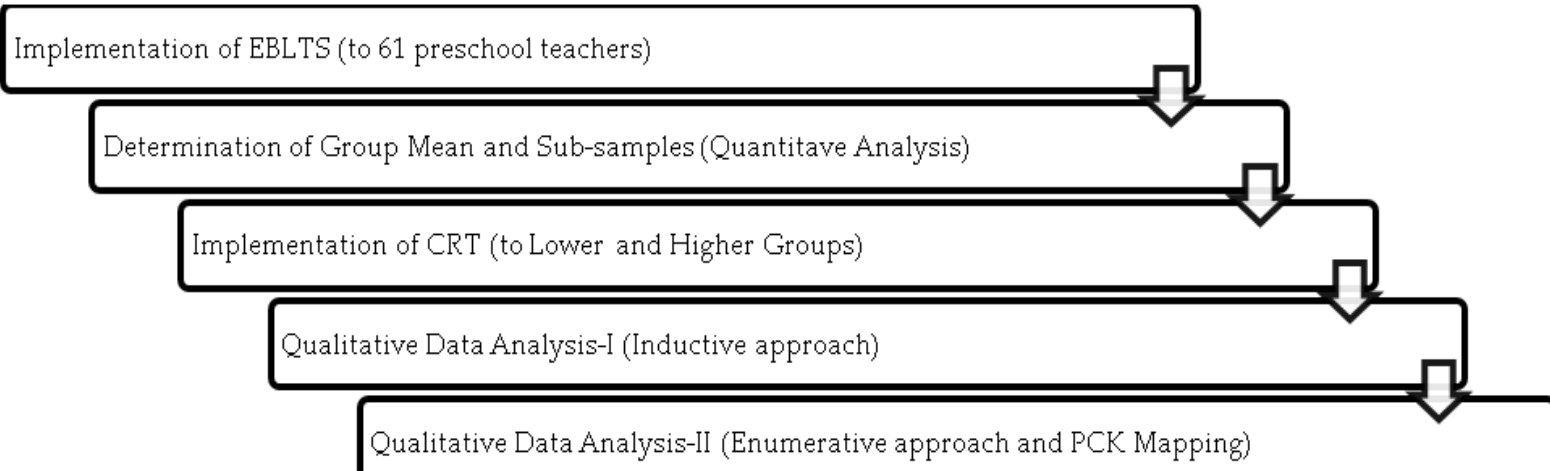

Figure 1. Steps

As seen in Figure 1, first of all, EBLTS was implemented for all participants. With the help of the quantitative data from here, the average scores and the participants in the sub-sample were determined. Afterward, participants with lower and higher epistemological beliefs responded to the CRT. Qualitative data from here were evaluated through inductive approach, in-depth explicit PCK analysis, enumerative approach, and PCK maps.

\section{Participants}

This study was conducted with 10 participants selected from 61 preschool teachers working in institutions affiliated with the Ministry of National Education (MoNE). These participants were also studying in the preschool teaching master's degree program of a foundation university in Turkey. These ten preschool teachers, representing at least $10 \%$ of the total participants, were selected according to the deviant sampling, one of the purposeful sampling methods (Palinkas et al., 2015). The quantitative epistemological belief scale was first applied to 61 preschool teachers in this process. The participants were divided into two sub-groups consisting of five persons each in a way to represent the lower and higher epistemological profiles, based on their scores obtained from this application (Figure 2). In order to determine more clearly how epistemological beliefs affect early science teaching pedagogy, two extreme epistemological profiles have been focused.

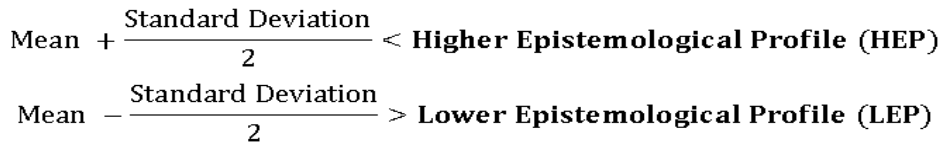

Figure 2. Sub-sampling process

As seen in Figure 2, if a participant's EBLTS score was more than the total of the arithmetic mean and half of the standard deviation, $\mathrm{S} /$ he was included in the higher epistemological profile. On the other hand, this was categorized as a low epistemological profile if a preschool teacher's EBLTS score was less than the difference between the arithmetic means and half of the standard deviation. The low epistemological profile represents a more precise and rhetorical perspective on structuring knowledge in learning-teaching processes. On the other hand, the higher epistemological profile represents a multidimensional perspective (Schommer-Aikins, 2004). Thus, it has been assumed that preschool teachers with lower and higher epistemological profiles have established and stable epistemological beliefs.

The information about the participants can be seen in Table 1. 
Table 1. Participants

\begin{tabular}{|c|c|c|c|c|c|c|c|}
\hline \multicolumn{2}{|c|}{ Teacher* } & Gender & School type & Children age & Teacher age & Professional experience & EBLTS scores \\
\hline \multirow{5}{*}{$\begin{array}{l}\text { Higher } \\
\text { group }\end{array}$} & HEP-1 & Female & Public & $48-60$ months & 24 & 4 years & 101 \\
\hline & HEP-2 & Female & Private & $36-48$ months & 30 & 5 years & 98 \\
\hline & HEP-3 & Male & Public & $48-60$ months & 34 & 8 years & 98 \\
\hline & HEP-4 & Female & Private & $48-60$ months & 25 & 4 years & 97 \\
\hline & HEP-5 & Female & Private & 60-72 months & 26 & 5 years & 96 \\
\hline \multirow{5}{*}{$\begin{array}{l}\text { Lower } \\
\text { group }\end{array}$} & LEP-1 & Female & Private & 60-72 months & 27 & 5 years & 59 \\
\hline & LEP-2 & Male & Public & $60-72$ months & 36 & 10 years & 59 \\
\hline & LEP-3 & Female & Public & $48-60$ months & 38 & 12 years & 58 \\
\hline & LEP-4 & Female & Public & $60-72$ months & 32 & 7 years & 56 \\
\hline & LEP-5 & Female & Private & $60-72$ months & 29 & 7 years & 56 \\
\hline
\end{tabular}

*For the study, teachers were given the pseudonym

As shown in Table 1, two of the participants, aged between 24 and 38, are male, and the others are female. The EBLTS scores of the participants in the sub-groups ranged from 56 to 101 . The scores of the lower group are between 56-59, while the scores of the higher group are between 96-101. In addition, the schools where participants who have different teaching experience work are located on the European side of Istanbul, the metropolitan city of Turkey. While there are 48-60-month-old children in the class of four participants, there are 60-72-month-old children in the class of five participants and 3648 -month-old children in the class of one participant.

\section{Data Collection Tools}

Two data collection tools were used to answer the sub-problems. These are the Epistemological Beliefs towards Learning and Teaching Scale (EBLTS) and Content Representation Task (CRT).

\section{Epistemological beliefs towards learning and teaching scale (EBSTL)}

To determine the epistemological beliefs of participants and include them in subgroups, EBSTL, which was developed by Sing-Chai et al. (2009) and adapted to the Turkish culture by Kutluca et al. (2018) was used. In the literature, many scales have been developed to measure teachers' epistemological beliefs and prospective teachers. But most of these are scales that focus on central or personal epistemological beliefs (Chan \& Elliott, 2002; Schommer, 1990; Schraw et al., 2002). On the other hand, the scale used in this study focuses on teachers' in-class teaching and practices. Therefore, it was thought that this scale would more consistently associate epistemological beliefs with early science teaching pedagogy. The scale consists of four sub-dimensions: access to knowledge, genetic nature versus absolute and single reality, and epistemic contradiction. Designed in five Likert-type, this scale has 23 items. The highest score to be obtained from the scale is 115 , while the lowest is 23 . The normative mean for the relevant scale is 69. According to descriptive statistics, the average of the whole group is $X=70.0$. On the other hand, the standard deviation value is 10.7. EBSTL scores of the participants assigned to the lower and higher epistemological profile are given in Table 1.

\section{Content representation task (CRT)}

Teachers' subject matter knowledge, pedagogical competencies, and conceptualizations are the most significant factors that are influential on their behaviors in the classroom and the learning level of their students (Park \& Oliver, 2008). However, it is known that the teacher knowledge, which represents all of these factors, has a complex structure due to the incorporation of content and pedagogy (Beyer \& Davis, 2012). For this reason, teachers' teaching cases for any subject matter should be integrated with tools that will represent different pedagogical structures (Nilsson, 2014). In addition, preschool teachers are expected to filter the existing knowledge structures epistemologically and ontologically when structuring science teaching processes for any subject matter (Andersson \& Gullberg, 2014). In this context, the content representation (CoRe) methodology was used to reveal the pedagogical conceptualizations of the early childhood science teaching of the teachers in different epistemological 
profiles involved in the research (Loughran et al., 2008). Accordingly, a CoRe endeavors to clarify teachers' holistic views on teaching a particular subject matter, based on big ideas, to make the implicit nature of teacher knowledge clear to others. So, a CoRe is designed to reveal teachers' knowledge to teach a particular concept (Nilsson \& Loughran, 2012). The CoRe task, adapted to the context of preschool education, was transformed into a lesson planning format and named CRT (Appendix A).

A preschool teacher who responds to the CRT determines the subject matter, big ideas or themes on this subject matter, curriculum-based learning outcomes, and scientific process skills related to these learning outcomes, respectively. He/she then makes content-based conceptualizations within the framework of the following themes:

- The scope and nature of the subject, concept, and big ideas required to be learned by children about the relevant subject matter,

- The way how children will integrate the relevant subject matter with the determined learning outcomes and scientific process skills,

- The reason why it's important for children to learn these ideas,

- Children's possible learning difficulties related to this concept and targeted learning outcomes and scientific process skills, and

- How these ideas fit in with the teacher's subject matter knowledge.

Expert opinions were asked to check the internal validity and external control of the questions in the CRT (McMillan \& Schumacher, 2010). These experts are researchers who specialize in PCK and early childhood science teaching. Then, a pilot application was performed with two preschool teachers who were not included in the participant group, and the answers obtained from this application were again transmitted to the experts. Following the feedback, the final version of the interview protocol was created. Before the implementation, the teachers were negotiated, and the process was planned together. No time and content limits were applied to the participants during the data collection process. The preschool teachers determined all the learning outcomes, subject areas, and scientific process skills. To obtain the qualitative data in writing more accurately, the explanations of the teachers who answered the questions were recorded with the help of a tape recorder. It took around 60 minutes for each teacher to answer the CRT.

\section{Research Ethics}

Before collecting data from the preschool teachers, they were informed about the purpose of the research, and it was stated that they could withdraw at any stage of the study. Due to scientific ethics, the names of the institutions and participants of the research are not disclosed. Instead, the participants were given pseudonyms. On the other hand, approval was obtained from the "Social and Human Sciences Ethics Committee" for the ethical evaluation of data collection tools.

\section{Data Analysis}

Data analysis was performed in a total of two steps and by means of five different data analysis methods. Firstly, the written conceptualizations of five teachers that were involved in the lower and higher epistemological profiles were arranged by matching them with their sound recordings by word for word. The first sub-problem in the study was answered through the inductive content analysis (Ezzy, 2013). This analysis method involves open coding, creating categories, and summarizing. Accordingly, the answers of preschool teachers to the CRT were firstly organized and divided into subcategories, and hence open coding was performed. Each subcategory, created based on the existing text, was read repeatedly, making sure that coding allowed for a rational theory (Elo \& Kyngas, 2008). 
Then the concepts obtained by open coding were grouped under the category lists. Creating categories aims to provide a way to describe phenomena, improve understanding, and create new objective knowledge (Bazeley, 2013). During formulating categories, the continuous comparison method was used to distinguish the conceptual similarities, develop the distinctive power of themes, and explore patterns (Fram, 2013). In this way, a methodological triangulation was provided, and summarizing was performed through context-specific concepts to create a general formulation (Morse, 1991). For example, three codes were obtained for the first question in the CRT (scientific literacy, concept teaching, life skills acquisition). At this point, it was coded as scientific literacy if the teacher referred to concepts such as scientific process skills, questioning, or reasoning while mentioning the purpose or orientation of teaching a particular subject matter. Moreover, the conceptual structures such as awareness or awareness-raising were grouped under the category of life skills acquisition.

The second sub-problem was answered using the PCK mapping method, a pictorial methodological representation. To achieve this, in-depth analysis of explicit PCK, enumerative approach, and analysis of PCK mapping were performed on the pedagogical conceptualizations of preschool teachers in two extreme epistemological profiles. In this process, all responses given by participants to the CRT were divided into sub-teaching sections. Each section here represents a unit of analysis (Fraenkel et al., 2012). The components integrated into the teacher's PCK for science teaching in a particular teaching section were identified by the in-depth analysis of explicit PCK (Park \& Oliver, 2008). The PCK interaction categories rubric developed by Aydin et al. (2015) was also considered. Thus, it was determined which PCK components were integrated into one another by teachers during the description of any teaching phenomenon. For example, the fact that teachers mention their favored pedagogical strategies during teaching to clarify early childhood science teaching targets shows an interaction between the OTS and KISR components. Or, the fact that teachers talk about various assessment strategies they use to identify students' difficulties, misunderstandings, or prerequisite knowledge shows the KSU-KAS interaction.

There are also other indications related to interactions between other components. The KISR-KSU interaction shows the use of a specific teaching strategy to overcome difficulties, misconceptions, or prior knowledge gaps. The KISR-KSC interaction represents using a specific teaching strategy to address a specific curriculum goal. When an interaction was detected in the data, it was noted that there was a (1) relation between the components corresponding to the interaction on the map. The more relations there are between a teacher's PCK components, the stronger the interaction is between the respective components. After in-depth analysis, the numbering approach and PCK mapping were used to quantify preschool teachers' interactions between PCK components (Park \& Chen, 2012).

Based on the assumption that at least a relation must be available between two PCK components defined within the selected teaching sections, the number of relations was counted, and directions of these relations were defined. Upon completion of the numbering process, the interactions defined in the model were reflected on PCK maps using the $P A B$ pentagon model as an analytical tool. Here, the pentagon model emphasizes the interaction between any two components (Friedrichsen et al., 2011). The mutual interactions and interdependence between the components indicate qualified teaching (Park, 2019). Therefore, in the Pentagon model, all PCK components have been expected to interact with each other in a balanced way. Therefore, it has important that the pentagonal structure in the model is completed.

During the analysis processes, the written responses of one preschool teacher each were sent to an expert researcher and subjected to a separate evaluation process (HEP-1; LEP-1). Here, the expert actively participated in content analysis, creation of teaching episodes, in-depth explicit PCK analysis, and PCK mapping processes.

- First, the relevant researcher was met, and the framework of each analysis step was negotiated and then evaluated separately. 
- Next, the expert conducted data analysis independently based on the established analysis framework.

- Then, the analysis results were compared, and the inter-coder reliability percentage was obtained (McMillan \& Schumacher, 2010).

$$
\text { Intercoder Reliability Percentage }=\frac{\text { Consensus }}{\text { Consensus }+ \text { Disagreement }} \times 100
$$

Accordingly, the number of units of analysis with which consensus was reached was proportioned to the total unit of analysis reached and turned into a percentage value. As a result, the inter-coder reliability percentage of the analyses at each step was found to be \%87 (content analysis), \%94 (teaching episodes), and \%93 (PCK analysis and mapping), respectively. These values indicate that the data analysis is reliable (Miles \& Huberman, 1994). The remaining forms were analyzed individually based on the defined criteria, and the results obtained by the analyses were evaluated together with the same expert to ensure external control.

\section{FINDINGS}

In this part of the research, the pedagogical conceptualizations made by preschool teachers in the lower and higher epistemological profile with the help of CRT were analyzed through different qualitative analysis approaches, and the results of the analysis were presented under two main headings. Firstly, the participants' pedagogical conceptualizations of early childhood science teaching were interpreted with the help of the themes and concepts given in Table 2. Then, the results of how epistemological belief differentiated PCK integration were given by means of PCK maps. 
Table 2. Themes and concepts about content-based pedagogical conceptualizations

\begin{tabular}{|c|c|c|}
\hline \multicolumn{2}{|c|}{ Categories } & \multirow[b]{2}{*}{$\begin{array}{l}\text { Themes \& concepts } \\
\text { Scientific literacy } \\
\text { Scientific process skills/Reasoning-Making decisions/Inquiry-Problem solving } \\
\text { Concept teaching } \\
\text { Energy-Colors-Nature } \\
\text { Life skills acquisition } \\
\text { Cleaning rules-Using in daily life/Becoming conscious-Gaining awareness }\end{array}$} \\
\hline $\bar{Q}-1^{*}$ & $\begin{array}{l}\text { The purpose or orientation of the } \\
\text { teacher to teach a particular subject }\end{array}$ & \\
\hline $\mathrm{Q}-2$ & $\begin{array}{l}\text { The orientation of the teacher } \\
\text { about why the topic that the } \\
\text { children want to learn is important }\end{array}$ & $\begin{array}{l}\text { Scientific literacy } \\
\text { Scientific process skills/Reasoning-Decision making/Research-Questioning } \\
\text { Concept teaching } \\
\text { Direct knowledge transfer/Indirect concept teaching } \\
\text { Citizenship-Character education } \\
\text { Life skills acquisition/Positive attitudes-Gaining awareness }\end{array}$ \\
\hline Q-3 & $\begin{array}{l}\text { The orientation of the teacher on } \\
\text { advanced and different knowledge } \\
\text { bases that children should not } \\
\text { learn yet }\end{array}$ & $\begin{array}{l}\text { Content structure (basic) } \\
\text { Subject matter knowledge/High-level knowledge/Parasite-Bacteria-Nutrition } \\
\text { Content structure (naive) } \\
\text { Energy-Colors-Nature/Raw-Direct knowledge }\end{array}$ \\
\hline Q-4 & $\begin{array}{l}\text { Teacher's orientation regarding the } \\
\text { teaching process regarding } \\
\text { difficulties, limitations and } \\
\text { disabilities }\end{array}$ & $\begin{array}{l}\text { Child-induced limitations } \\
\text { Preliminary knowledge/Developmental features } \\
\text { Children's cognitive level/Motivation-Apathy } \\
\text { Content-based limitations } \\
\text { Subject context/Difficulties of implementation } \\
\text { External limitations } \\
\quad \text { Number of children in class/Lack of material/Lack of time }\end{array}$ \\
\hline Q-5 & $\begin{array}{l}\text { The orientation of the teacher } \\
\text { about child concepts that affect } \\
\text { teaching on a particular subject }\end{array}$ & $\begin{array}{l}\text { Cognitive features } \\
\text { Level of children's cognition/Creative worlds of children/Question formats } \\
\text { Epistemological perspectives/Gripping difficulties } \\
\text { Experiences } \\
\text { Scarcity of informal experience/Lack of motivation-Apathy }\end{array}$ \\
\hline Q-6 & $\begin{array}{l}\text { The orientation of the teacher on } \\
\text { teaching approaches, strategies } \\
\text { and techniques related to a } \\
\text { particular subject }\end{array}$ & $\begin{array}{l}\text { Child-centered strategies } \\
\text { Learning by discovering/Problem-based learning/Cooperative learning } \\
\text { Experiments-Question answer/Story-Case studies-Drama } \\
\text { Research-Inquiry } \\
\text { Qualified questioning activities/Scientific process skills } \\
\text { Negotiation processes/Large-Small group discussions }\end{array}$ \\
\hline Q-7 & $\begin{array}{l}\text { Strategies offered by the teacher to } \\
\text { identify children's understanding } \\
\text { and confusion about the topic } \\
\text { taught }\end{array}$ & $\begin{array}{l}\text { Use of strategy } \\
\text { Observation-Question \& answer/Discussion } \\
\text { Reporting of results (-) }\end{array}$ \\
\hline Q-8 & $\begin{array}{l}\text { Teacher's orientation towards } \\
\text { academic or non-academic } \\
\text { teaching approaches and subject } \\
\text { area knowledge resources }\end{array}$ & $\begin{array}{l}\text { Primary resources } \\
\text { Research articles } \\
\text { Secondary sources } \\
\text { Web } 2.0 \text { tools-Blogs/Internet sites } \\
\text { Teacher competence } \\
\text { Experience/Certificate programs/Technology proficiency }\end{array}$ \\
\hline
\end{tabular}

\section{Content-Based Conceptualizations of Early Childhood Science Teaching}

The level of learning outcomes of the curriculum, subject matter contents, and scientific process skills that all teachers plan to teach children through the science teaching activities they designed were first evaluated. All teachers designed a science teaching activity based on a different subject. On the other side, it was found that participants with a higher epistemological profile had more scientific process skills they intended to teach. Each of the teachers in the higher group indicated at least three scientific process skills (e.g., HEP-3; Observing, Predicting, Communicating, and Inferring), while those in the lower group indicated at most two scientific process skills (e.g., LEP-5; Observing). This situation is also similar in terms of the learning outcomes determined by teachers. While the teachers with higher epistemological beliefs diversified their curriculum-based learning outcomes on the basis of different levels, the teachers with lower epistemological beliefs either could not remember the learning outcomes or reflected a limited perspective. For example, HEP-4 planned his instruction based on the learning 
outcomes named "She/he groups objects or entities by their properties," "She/he establishes a causeeffect relationship," and "She/he offers solutions to problem situations" (his subject area was force and motion). LEP-4, in contrast, planned his instruction based on the learning outcome named "She/he compares the properties of objects or entities" (his subject area was natural events).

On the other hand, Table 2 presents the CRT-based pedagogical conceptualizations of preschool teachers in the lower and higher epistemological profiles. Accordingly, the teachers in the higher group were found to have responded, the question about the teacher's purpose or orientation to teach a particular subject matter, with a perspective based on the vision of science literacy, whereas the teachers in the lower group focused only on teaching concepts.

For example, HEP-3 suggests that children should acquire scientific process skills based on questioning and problem solving, while LEP-3 focuses on specific concepts based on plant growth. On the other side, both teacher groups considered life skills acquisition important. Here, HEP-1 emphasizes the skills that children can use in everyday life in the context of the theme of cleanliness, while LEP-4 offers a content-based perspective on the theme of natural events, focuses on raising awareness.

Considering the participants' answers for the second question, it was revealed that both groups referred to the themes of concept teaching and citizen-character education. For example, it was highlighted by HEP4 that the teaching activity in the context of the buoyancy of liquids is significant in terms of 'internalizing everyday skills, basic scientific process skills and concepts in an indirect 'way'. On the other hand, LEP-1 discussed the direct concept teaching by referring to the importance of the subject context in the current science teaching activity regarding awareness-raising. The major difference here is that the teacher having higher epistemological belief refers to indirect concept teaching rationale, and the teacher with the lower level of epistemological belief refers to the direct concept teaching rationale. Another difference that distinguishes the high-group participants from the lower-group participants in light of the answers to the second question is that they detail the rationale for science literacy.

HEP-2: It is expected that the student will process the knowledge obtained by observation and use of classification skills to make inferences about the form of nutrition. In this way, children's scientific skills and inquiries will be improved.

HEP-3: Above all, it is important for children to perceive that everything is important for ecological balance, to conduct research on the experienced problems when necessary, to suggest solutions based on the scientific knowledge about the problem, and to discuss it themselves.

The answers of the two participants from the higher epistemological profile indicated that they emphasized the scientific process, questioning, and reasoning skills that represent the basic learning outcomes to allow children to become science-literate individuals. This suggests that they have adopted the basic rationales for qualified early childhood science teaching. Considering the answers of the preschool teachers in the lower and higher groups to the third question about the bases of the advanced and different knowledge not required to be learned by children yet, it was seen that the participants having higher epistemological belief addressed the basic content structure in line with the children's developmental level rationale, while the participants with lower epistemological belief suffered from irresolution. HEP-1 noted that he/she transformed the content to be shared during the science teaching activity, in the context of cleanliness based on the scientific process skills such as observation and prediction within the age group of children and talked about some harmful bacteria species as an example of advanced knowledge. However, she stated that she would not specifically mention Staphylococcus and Micrococcus bacteria. LEP-2, on the other hand, preferred to address the origin of the subject matter rather than talking about the advanced knowledge structures on the subject. According to him, children should be directed to chemically and naturally occurring dyes. He thought that children could learn more healthily this way. 
The fourth question in the CRT represents the orientations of teachers towards the challenges, limitations, and obstacles associated with the teaching process. The conceptualizations of preschool teachers who answered this question are independent of their epistemological beliefs. Therefore, both participant groups referred to child-based, content-based, and external limitations. For example, HEP-5 stated that especially the application part of the subject matter teaching would have some difficulties in terms of student understanding, application difficulty, and class size. Similarly, it was seen in the explanation of LEP-5 that the concepts of motivation-indifference, subject context, and lack of materials became prominent.

As a result of the participant's responses to the fifth question, it was discovered that both groups referred to the same two themes: cognitive characteristics and experiences. The preschool teachers in this research believe that 'children's interests and experiences and the creative nature they have influence their teaching 'activities'. Accordingly, it can be suggested that the epistemological beliefs of the participants did not change their orientation towards student understandings and misconceptions. The qualitative data analysis performed on the answers to the sixth question revealed that all participants from the lower and higher epistemological profiles tended to use child-centered strategies.

HEP-1: I manage the process by guiding children in this subject's teaching and application stages. I learn the level of children's ideas on the subject matter by means of some questions I ask in advance. Then, I give the necessary information about the subject matter, pour colored glitter on the hands of the children as a representative microbe, and want them to make examinations, observe their hands and try to remove the glitter in a dry way. I want them to think about how we can get rid of these microbes (glitter) and express themselves. Then, they endeavor to get rid of the microbes by using just water, but when they observe that they cannot be purified, they see that the microbes (glitter) slide when they apply again, using the soaps they want this time.

LEP-2: I use the method of asking questions. For example, I start the process by asking what colors are, and how colors are formed. Cooperative learning. In the process, children work in collaboration, creating natural colors. They all benefit from the questions asked and the answers given. Children learn by doing and experiencing themselves in active learning and realize the application processes themselves. Only in situations that may be dangerous does the teacher step in (such as mixing hot water).

Accordingly, HEP-1 enriches the child-centered instructional strategies with qualified qualifying questions during the science teaching activity and allows children to learn by discovery. On the other hand, LEP-2 enriched the collaborative teaching with the question-answer technique. Here, the main difference that distinguishes HEP-1 from LEP-2 is that the former involves inquiry activities that will help children acquire scientific process skills in the teaching practices. In the above-mentioned example, the high-group teachers inviting children to negotiation processes in each pedagogical move may verify this.

The findings on the seventh question on what and how preschool teachers will assess in science teaching show that both groups of participants have conflicting ideas about assessment and evaluation. It is an indicator of this situation that the participants focus more on the use of strategy in their conceptualization of this question, and they neglect the reporting of the results. For example, HEP-3 and LEP-3 referred to the question-answer technique. But they did not mention anything about the results of the evaluation. Finally, the last question in CRT represents the participants' orientations towards academic or nonacademic teaching approaches and subject matter knowledge resources. This question, which can expand the scope of the other seven questions, revealed that the teachers with higher epistemological beliefs referred to primary sources, and the teachers with lower epistemological beliefs referred to secondary sources. For example, HEP-2 noted his/her need for peer interaction and primary sources such as articles and dissertations to expand its teaching perspective. LEP-4, on the other hand, was found to tend to use technological tools but needed secondary resources such as books. 
Interactions Between PCK Components for Early Childhood Science Teaching

To define the impact of epistemological beliefs on PCK integrations for the early childhood science teaching, the teaching sections of preschool teachers in the lower and higher groups were firstly combined, and the number of teaching sections on a group basis and the binary relations between PCK components were defined (Table 3).

Table 3. Teaching episodes and dyads

\begin{tabular}{lcc}
\hline & Teaching episode & Dyad connections among components \\
\hline HEP & 57 & 152 \\
LEP & 36 & 78 \\
\hline
\end{tabular}

It is indicated by the results in Table 3 that the preschool teachers with higher epistemological beliefs have more teaching sections within the scope of early childhood science teaching than those offered by the teachers with lower epistemological beliefs. Furthermore, it was also revealed that the binary relations between the PCK components in the teaching sections of the preschool teacher group representing the higher epistemological profile were more. Accordingly, it can be suggested that the participants with higher epistemological beliefs extend their pedagogical conceptualizations to a broader scope.

Figure 3 presents the PCK maps created following the analyses performed to define how epistemological beliefs about learning to change the interaction between PCK components. Accordingly, it is observed that the strongest interactions between PCK components of preschool teachers in the lower epistemological profile are between KSU-OTS (26\%) and KSU-KISR (21\%). In addition, KSU $(28 \%)$, KISR $(27 \%)$, and OTS $(24 \%)$ were the components that interacted the most with other components from the teaching sections of participants included in the lower epistemological profile. On the other hand, no interaction was found between KSC-KAS, and that the binary relations between other components except OTS-KISR (12\%) and KISR-KAS (16\%) were quite weak. It was discovered that KSC (9\%) was the component that interacted the least with other components among the teaching sections of the participants involved in the lower epistemological profile.

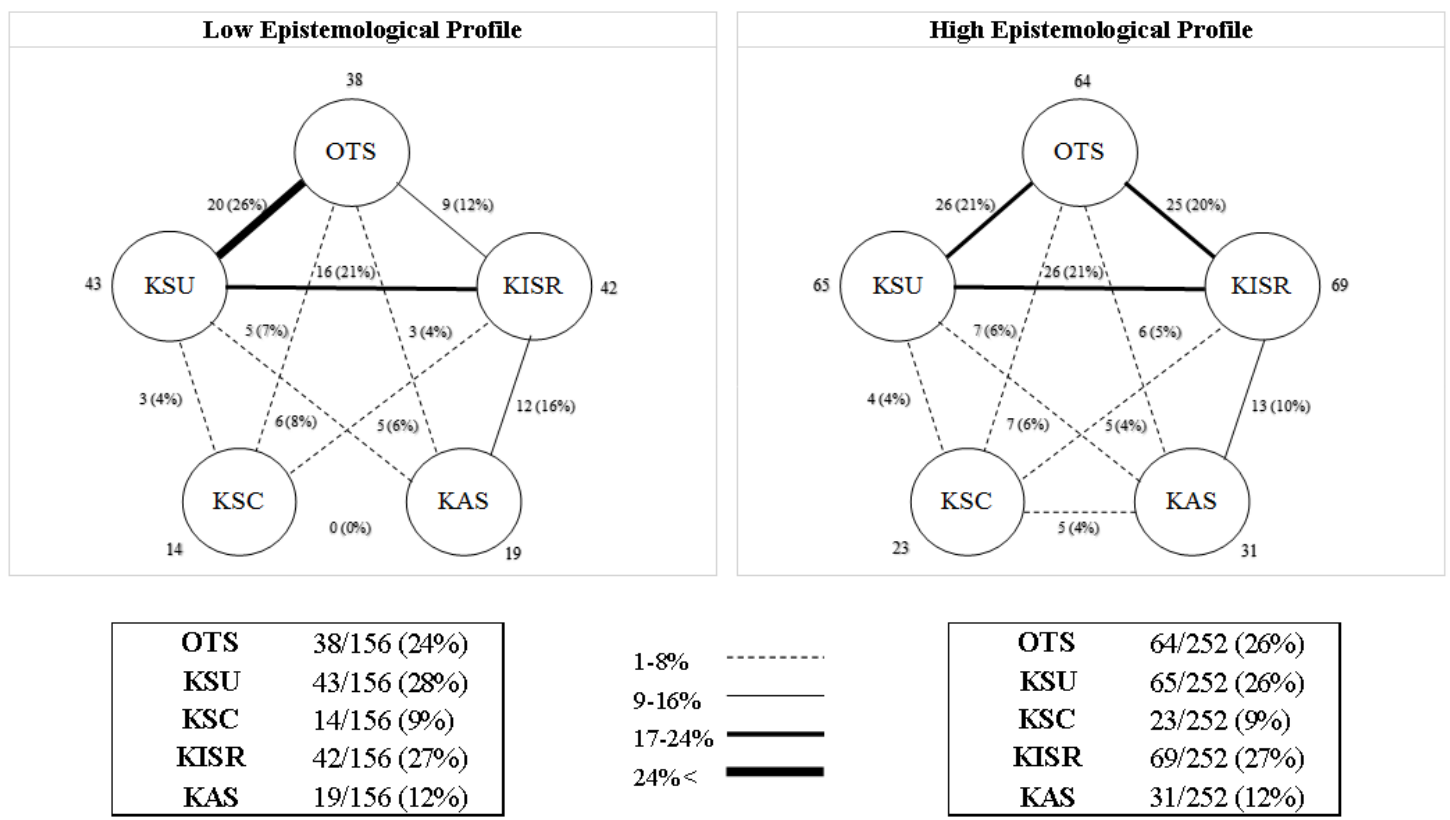

Figure 3. The effect of epistemological belief on PCK integration

LEPкsu-отs: To protect natural energy resources by raising awareness on what energy is, its function, and what the natural energy sources are. To understand the importance of saving energy. To take part in the society as a conscious consumer role for himself/herself and his/her environment by raising awareness on energy saving. 
LEРкsu-кіsR: Children learned by doing and experiencing themselves and realized the application processes themselves. Only in situations that might be dangerous did the teacher step in (such as mixing hot water). Since we use experimental method, children do not experience concept confusion with respect to this knowledge. Our work becomes easier because they do not know anything about science.

The two sample quotations, which represent the components that interact the most, revealed that participants in the lower epistemological profile mostly based their pedagogical conceptualizations on their understanding of children. Accordingly, the example of KSU-OTS shows that the participant with lower epistemological beliefs directly bases his/her explanation on the concept of teaching and awareness-raising rationales. It can be said that another participant from the lower epistemological profile presenting the KSU-KISR example thinks their understanding of children is very limited and tends to neglect child cognition in relation to prior knowledge and experiences.

Considering the PCK map of the higher epistemological profile, a more balanced interaction was found between the components. Accordingly, the strongest interactions between PCK components are seen between KSU-OTS (21\%), KSU-KISR (21\%), and OTS-KISR (20\%). In addition, KISR (27\%), KSU (26\%), and OTS $(26 \%)$ are the components that interacted the most with other components from the teaching sections of participants included in the higher epistemological profile. On the other hand, it was found that the binary relation between KSC-KAS (4\%) was quite weak. It was discovered that KSC (9\%) was the component that interacted the least with other components among the teaching sections of the participants involved in the higher epistemological profile.

НЕРкли-отs: My target for science teaching is to help children make observations about the event/situation and be aware of the basic rules of nature by creating environments in which they can freely express their thoughts. In this way, I also provide a pre-learning environment related to the subject concept that I want to teach with the effect of discovery and communication skills.

HEPкsu-kisR: Since the attention span of children is short because of their age, I try to make science teaching more understandable for children by using visual and auditory materials, in the teaching process that can draw more attention and support their active use of senses.

HEPотs-KISR: I actually think that the subject matter used serves as an instrument for the scientific process skills expected to be displayed as a goal. I find what the goal is more important not what the instrument is. For this, I think it is important for children to learn by discovery.

Compared to the sample quotes of the lower epistemological profile on the relations between PCK components, it is revealed that the higher epistemological profile, in particular, strengthens the KSUOTS-KISR triple chain with strong interaction and rationalizes the concept of teaching as an instrument rather than a goal.

\section{DISCUSSION}

This study examined how the preschool teachers' pedagogical conceptualizations of early childhood science teaching changed by their epistemological beliefs. In this research conducted through an exploratory case study, five participants, each with lower and higher epistemological beliefs, were selected and involved in the qualitative data collection process. The results that were obtained following the qualitative data analyses on the data collected in this way were discussed in the light of the relevant literature.

First of all, the preschool teachers' epistemological beliefs in the research are above the normative average (69.00). However, the mean scores of the whole group $(X=70.0)$ are lower than the sum of the normative mean and standard deviation $(X=79.7)$. This result shows that the participant group has a more precise or rhetorical understanding of knowledge construction about epistemological beliefs. In addition, this result is consistent with the findings of early childhood teacher education studies (Bedel, 2012; Ugras \& Cil, 2016). The main expectation in the literature for early childhood science teaching is 
that preschool teachers have a multifaceted orientation towards knowledge and knowing and adopt a constructivist epistemology (Akerson et al., 2011; Brownlee et al., 2011). However, research findings do not support this idea. Therefore, participating teachers may resist using child-centered and science literacy-related approaches to early science teaching (Brownlee \& Berthelsen, 2006).

\section{The Effect of Epistemological Beliefs on Content-Based Pedagogical Conceptualizations}

The content-based conceptualizations of the preschool teachers from the lower and higher epistemological profiles indicate that epistemological beliefs towards learning change the quality of science teaching in certain aspects. First, the participants with higher epistemological beliefs tend to perform science teaching based on indirect concept teaching and science literacy vision, while the participants with lower epistemological beliefs tend to do it based on direct knowledge transfer and concept teaching (e.g., Akerson et al., 2011; National Research Council, 2013). This supports the suggestion that preschool teachers who perform science teaching should integrate content and pedagogy properly with their teaching goals and orientations (Neuman \& Danielson, 2021). Moreover, many researchers have put forward that the epistemological beliefs of preschool teachers determine their pedagogical structures (e.g., Brownlee et al., 2011; Mansour, 2013). Accordingly, the pedagogical structures that arise from a creative process influenced by beliefs and knowledge interactions from different categories determine the quality of teachers' in-class teaching (Brown, 2009). The results of this research also show that the epistemological beliefs of preschool teachers influence their pedagogical structures. Another result on the quality of the early childhood science teaching determined that preschool teachers tended to adopt the child-centered teaching strategies independently of their epistemological beliefs during science teaching. However, the participants from the higher epistemological profile highlighted the inquiry-based teaching approaches. This result essentially supports the focus of the current literature on the pedagogical strategy, which offers a modern perspective on early childhood science teaching (Areljung, 2019; Larimore, 2020). On the other hand, epistemological beliefs enable preschool teachers to have an inquiry-based teaching understanding, which is the prominent conclusion. Accordingly, the inquiry activities serving as a powerful instrument for children when discovering the world with their curiosity are possible with preschool teachers with higher epistemological beliefs (Sackes et al., 2013; Wright \& Gotwals, 2017).

The teacher's primary role in early childhood science teaching is to help children' explore scientific concepts through hands-on play rather than providing experiment-based passive learning environments (Hamel et al., 2021). To achieve this, preschool teachers must shift from a teacher-centered epistemology to a child-centered and social constructivist epistemology (Fleer, 2013, 2019). These results revealed that there should be an increased interest in epistemological orientations in order to improve preschool teacher education in the context of science teaching.

\section{The Effect of Epistemological Beliefs on PCK Integrations}

To indicate how epistemological belief changes the quality of early childhood science teaching, PCK maps were created based on the CRT responses of preschool teachers involved in the lower and higher epistemological profiles. In this way, the change of interactions between PCK components embedded in the preschool teachers' conceptualizations of the early childhood science teaching was defined. The PCK map, which indicates that the teacher's teaching of any subject matter based on a pictorial methodological approach, is expected to have a consistent and holistic structure of the interaction between the components that form it (Park \& Chen, 2012). According to the results of this research, PCK maps of the preschool teachers with higher epistemological beliefs have a more holistic structure. Although some early science education and PCK researchers (Andersson \& Gullberg, 2014; GessNewsome, 2015; Karabon, 2021) argue that orientations play an important role in developing PCK and changing teaching practice, no research pays specific attention to epistemological orientations in the context of early science teaching and PCK. However, the aforementioned finding supports the findings of Suh and Park's (2017) research in the context of $5^{\text {th }}$-grade students. Researchers have determined that 
epistemological orientations strengthen PCK interaction. Therefore, qualified early childhood science teaching is possible only when the preschool teachers with higher epistemological beliefs can integrate the content and pedagogy through different components (Davis et al., 2016; Larimore, 2020).

It was determined that both groups of teachers interacted with the components of OTS, KSU, and KISR strongly with each other. This conclusion supports the findings of other research conducted based on PCK interaction (Demirdogen, 2016; Park \& Chen, 2012). Given that the most basic expectation of early childhood education literature (e.g., NSTA, 2014; Larimore, 2020) for science teaching is the integration of content and child-centered pedagogical strategies based on proper approaches, it is revealed that preschool teachers meet this expectation independently of their epistemological beliefs. On the other hand, it was revealed that both groups of teachers could not sufficiently integrate assessment and evaluation and curriculum components into early childhood science teaching. This result has been supported the findings of the studies performed with the teachers having students at different grade levels and teachers from different branches (e.g., Davis et al., 2014; Kutluca, 2021a; Park \& Chen, 2012). For example, Gao et al. (2021), who examined how PCK components were integrated during a middle school teacher's teaching of natural selection, found that assessment knowledge had the most limited link with other components. On the other hand, Suh and Park (2017), who worked with experienced $5^{\text {th }}$ grade teachers, found that knowledge of curriculum and assessment have interacted least with other components.

On the one hand, the participants' focus on rigorous teaching practices may appear to be a strength. However, these practices are not strongly associated with the curriculum poses a problem in terms of early science teaching standards (MoNE, 2013; NSTA, 2014; Wilinski, 2017). Considering that early childhood science teaching should be handled holistically (Larimore, 2020), it has emerged that preschool teacher education should focus on this aspect. Furthermore, Brenneman (2011) argues that assessments in the context of early childhood science teaching will be easier through curriculum integration. Accordingly, a preschool teacher who wants to evaluate individual children's learning and skills needs to know what the curriculum expects from her/him. Unfortunately, the research results revealed that preschool teachers are inadequate in terms of the two PCK components mentioned.

\section{CONCLUSION AND IMPLICATIONS}

This study investigated the impact of epistemological beliefs on the preschool teachers' pedagogical conceptualizations of science teaching. The results obtained by the analyses using different methodological approaches showed that the participating preschool teachers had a rhetorical understanding of knowledge construction. Preschool teachers with higher epistemological beliefs referred more to the science literacy vision in science teaching. These teachers tend to integrate their teaching strategies more with inquiry-based teaching approaches. On the other hand, epistemological beliefs enabled preschool teachers to holistically consider science teaching. However, regardless of epistemological beliefs, preschool teachers could not associate assessment and curriculum components with each other.

In conclusion, these results showed that the interaction between epistemological beliefs and early childhood science teaching conceptualizations had a complex nature, consistent with the literature. It can be thought that this complex structure is especially related to the nature of data collection tools. First of all, unlike other studies (Ugras \& Cil, 2016; Wu et al., 2021) this study has been focused on epistemological beliefs about learning and teaching. In addition, the CoRe methodology has been used, which delicately integrates content and pedagogy for early childhood science teaching. Finally, the results have been presented based on different methodological approaches. All these have led to healthier and more in-depth interpretations specific to early childhood education. In this way, possible limitations have been overcome. 
In the light of the discussion of these results, some specific recommendations can be made by considering different contexts. First, exploring preschool teachers' epistemological beliefs through larger quantitative studies may provide useful information to the literature. The multifaceted effects of in-service training in which epistemology and early science teaching are contextualized can also be investigated. In addition, in-service training can be carried out to allow preschool teachers with lower epistemological profiles to be included in the school system. Secondly, it was determined that preschool teachers had problems in contextualizing curriculum and assessment knowledge with early science teaching. Therefore, in-service training focusing on this scope will be effective. Finally, specific research can be conducted to explore how epistemological beliefs affect the contextualization of curriculum and assessment information with early science teaching.

Author contributions: All authors were involved in concept, design, collection of data, interpretation, writing, and critically revising the article. All authors approve final version of the article.

Funding: The authors received no financial support for the research and/or authorship of this article.

Declaration of interest: Authors declare no competing interest.

Data availability: Data generated or analysed during this study are available from the authors on request.

\section{REFERENCES}

Abell, S. K. (2008). Twenty years later: Does pedagogical content knowledge remain a useful idea? International Journal of Science Education, 30(10), 1405-1416. https://doi.org/10.1080/09500690802187041

Akerson, V. L., Buck, G. A., Donnelly, L. A., Nargund-Joshi, V., \& Weiland, I. S. (2011). The importance of teaching and learning nature of science in the early childhood years. Journal of Science Education and Technology, 20(5), 537-549. https://doi.org/10.1007/s10956-011-9312-5

Alexander, R. (2004). Still no pedagogy? Principle, pragmatism and compliance in primary education. Cambridge Journal of Education, 34(1), 7-33. https://doi.org/10.1080/0305764042000183106

Andersson, K., \& Gullberg, A. (2014). What is science in preschool and what do teachers have to know to empower children? Cultural Studies of Science Education, 9(2), 275-296. https://doi.org/10.1007/s11422-012-9439-6

Appleton, K. (2006). Science pedagogical content knowledge and elementary school teachers. In K. Appleton (Ed.), Elementary science teacher education: International perspectives on contemporary issues and practice (pp. 31-54). Lawrence Erlbaum Associates.

Areljung, S. (2019). Why do teachers adopt or resist a pedagogical idea for teaching science in preschool? International Journal of Early Years Education, 27(3), 238-253. https://doi.org/10.1080/09669760.2018.1481733

Arias, A. M., Davis, E. A., Marino, J. C., Kademian, S. M., \& Palincsar, A. S. (2016). Teachers' use of educative curriculum materials to engage students in science practices. International Journal of Science Education, 38(9), 1504-1526. https://doi.org/10.1080/09500693.2016.1198059

Aydin, A., \& Guney, M. Y. (2017). The effects of activities developed in accordance with the constructivist approach on pre-school teacher candidates' learning the science concepts. Journal of Kirsehir Education Faculty, 18(1), 181-201.

Aydin, S., Demirdogen, B., Akin, F. N., Uzuntiryaki-Kondakci, E., \& Tarkin, A. (2015). The nature and development of interaction among components of pedagogical content knowledge in practicum. Teaching and Teacher Education, 46, 37-50. https://doi.org/10.1016/j.tate.2014.10.008

Barenthien, J. M., \& Dunekacke, S. (2021). The implementation of early science education in preschool teachers' initial teacher education. A survey of teacher educators about their aims, practices and challenges in teaching science. Journal of Early Childhood Teacher Education, 1-19. https://doi.org/10.1080/10901027.2021.1962443

Barenthien, J., Lindner, M. A., Ziegler, T., \& Steffensky, M. (2020). Exploring preschool teachers' science-specific knowledge. Early Years, 40(3), 335-350. https://doi.org/10.1080/09575146.2018.1443321

Bauer, J. R., \& Booth, A. E. (2019). Exploring potential cognitive foundations of scientific literacy in preschoolers: Causal reasoning and executive function. Early Childhood Research Quarterly, 46, 275-284. https://doi.org/10.1016/j.ecresq.2018.09.007

Bazeley, P. (2013). Qualitative data analysis: Practical strategies. SAGE.

Bedel, E. F. (2012). An examination of locus of control, epistemological beliefs and metacognitive awareness in preservice early childhood teachers. Educational Sciences: Theory and Practice, 12(4), 3051-3060.

Bell, R. L., \& Clair, T. L. S. (2015). Too little, too late: Addressing nature of science in early childhood education. In K. C. Trundle, \& M. Sackes (Eds.), Research in early childhood science education (pp.125-141). Springer. https://doi.org/10.1007/978-94-0179505-0_6

Beyer, C. J., \& Davis, E. A. (2012). Developing preservice elementary teachers' pedagogical design capacity for reform-based curriculum design. Curriculum Inquiry, 42(3), 386-413. https://doi.org/10.1111/j.1467-873X.2012.00599.x 
Brenneman, K. (2011). Assessment for preschool science learning and learning environments. Early Childhood Research \& Practice, 13(1), 1-9.

Broström, S. (2015). Science in early childhood education. Journal of Education and Human Development, 4(2), 107-124. https://doi.org/10.15640/jehd.v4n2_1a12

Brown, M. W. (2011). The teacher-tool relationship: Theorizing the design and use of curriculum materials. In J. T. Remillard, B. A. Herbel-Eisenmann, \& G. M. Lloyd (Eds.), Mathematics teachers at work: Connecting curriculum materials and classroom instruction (pp. 17-36). Routledge. https://doi.org/10.1080/14681994.2010.526102

Brownlee, J. (2001). Epistemological beliefs in pre-service teacher education students. Higher Education Research E Development, 20(3), 281-291. https://doi.org/10.1080/07294360120108377

Brownlee, J. M., Edwards, A., Berthelsen, D. C., \& Boulton-Lewis, G. M. (2011). Self-authorship in childcare student teachers. In G. Schraw, J. J. Brownlee, \& D. Berthelsen (Eds.), Personal epistemology and teacher education (pp. 68-83). Routledge. https://doi.org/10.4324/9780203806616

Brownlee, J., \& Berthelsen, D. (2006). Personal epistemology and relational pedagogy in early childhood teacher education programs. Early Years, 26(1), 17-29. https://doi.org/10.1080/09575140500507785

Brownlee, J., Boulton-Lewis, G., \& Berthelsen, D. (2008). Epistemological beliefs in childcare: Implications for vocational education. British Journal of Educational Psychology, 78(3), 457-471. https://doi.org/10.1348/000709907X262503

Bybee, R. W. (2013). The next generation science standards and the life sciences. Science and Children, 50(6), 25-32.

Chan, K. K. H., \& Hume, A. (2019). Towards a consensus model: Literature review of how science teachers' pedagogical content knowledge is investigated in empirical studies. In A. Hume, R. Cooper, \& A. Borowski (Eds.), Repositioning pedagogical content knowledge in teachers' knowledge for teaching science (pp. 3-76). Springer. https://doi.org/10.1007/978-981-13-5898-2_1

Chan, K. W., \& Elliott, R. G. (2002). Exploratory study of Hong Kong teacher education students' epistemological beliefs: Cultural perspectives and implications on beliefs research. Contemporary Educational Psychology, 27(3), 392-414. https://doi.org/10.1006/ceps.2001.1102

Charlesworth, R., \& Lind, D. (2010). Science and math for young children. Delmar.

Chen, J. A. (2012). Implicit theories, epistemic beliefs, and science motivation: A person-centered approach. Learning and Individual Differences, 22(6), 724-735. https://doi.org/10.1016/j.lindif.2012.07.013

Davis, E. A., Janssen, F. J., \& Van Driel, J. H. (2016). Teachers and science curriculum materials: Where we are and where we need to go. Studies in Science Education, 52(2), 127-160. https://doi.org/10.1080/03057267.2016.1161701

Davis, E., Palincsar, A. S., Arias, A. M., Bismack, A. S., Marulis, L., \& Iwashyna, S. (2014). Designing educative curriculum materials: A theoretically and empirically driven process. Harvard Educational Review, 84(1), 24-52. https://doi.org/10.17763/haer.84.1.g48488u230616264

Demirdogen, B. (2016). Interaction between science teaching orientation and pedagogical content knowledge components. Journal of Science Teacher Education, 27(5), 495-532. https://doi.org/10.1007/s10972-016-9472-5

Denzin, N. K. (2012). Triangulation 2.0. Journal of Mixed Methods Research, 6(2), 80-88. https://doi.org/10.1177/1558689812437186

Duran, M., Usak, M., Hsieh, M. Y., \& Uygun, H. (2021). A new perspective on pedagogical content knowledge: Intellectual and emotional characteristics of science teachers. Revista de Cercetare si Interventie Sociala [Journal of Research and Social Intervention], 72, 9-32. https://doi.org/10.33788/rcis.72.1

Elo, S., \& Kyngäs, H. (2008). The qualitative content analysis process. Journal of Advanced Nursing, 62(1), 107-115. https://doi.org/10.1111/j.1365-2648.2007.04569.x

Erden, F. T., \& Sonmez, S. (2011). Study of Turkish preschool teachers' attitudes toward science teaching. International Journal of Science Education, 33(8), 1149-1168. https://doi.org/10.1080/09500693.2010.511295

Ezzy, D. (2013). Qualitative analysis. Routledge. https://doi.org/10.4324/9781315015484

Fleer, M. (2013). Collective imagining in play. In I. Schousboe, \& D. Winther-Lindqvist (Eds.), Children's play and development (pp. 73-87). Springer. https://doi.org/10.1007/978-94-007-6579-5_5

Fleer, M. (2019). The role of subjectivity in understanding teacher development in a scientific playworld: The emotional and symbolic nature of being a teacher of science. In F. González Rey, A. Mitjáns Martínez, \& D. Magalhães Goulart (Eds.), Subjectivity within cultural-historical approach (pp. 149-164). Springer. https://doi.org/10.1007/978-981-13-3155-8_9

Flick, U. (2018). Triangulation in data collection. SAGE. https://doi.org/10.4135/9781526416070.n34

Fraenkel, J. R., Wallen, N. E., \& Hyun, H. H. (2012). How to design and evaluate research in education. McGraw-Hill.

Fram, S. M. (2013). The constant comparative analysis method outside of grounded theory. Qualitative Report, 18(1), 1-25.

Gao, S., Damico, N., \& Gelfuso, A. (2021). Mapping and reflecting on integration of the components of pedagogical content knowledge (PCK) for teaching natural selection: A case study of an experienced middle-school science teacher. Teaching and Teacher Education, 107, 103473. https://doi.org/10.1016/j.tate.2021.103473

Gerde, H. K., Pierce, S. J., Lee, K., \& Van Egeren, L. A. (2018). Early childhood educators' self-efficacy in science, math, and literacy instruction and science practice in the classroom. Early Education and Development, 29(1), 70-90. https://doi.org/10.1080/10409289.2017.1360127 
Gerring, J. (2004). What is a case study and what is it good for? American Political Science Review, 98(2), 341-354. https://doi.org/10.1017/S0003055404001182

Gess-Newsome, J. (2015). A model of teacher professional knowledge and skill including PCK: Results of the thinking from the PCK Summit. In A. Berry, P. Friedrichsen, \& J. Loughran (Eds.), Re-examining pedagogical content knowledge in science education (pp. 38-52). Routledge. https://doi.org/10.4324/9781315735665-8

Gess-Newsome, J., Taylor, J. A., Carlson, J., Gardner, A. L., Wilson, C. D., \& Stuhlsatz, M. A. (2019). Teacher pedagogical content knowledge, practice, and student achievement. International Journal of Science Education, 41(7), 944-963. https://doi.org/10.1080/09500693.2016.1265158

Gopnik, A. (2012). Scientific thinking in young children: Theoretical advances, empirical research, and policy implications. Science, 337(6102), 1623-1627. https://doi.org/10.1126/science.1223416

Graue, M. E., Whyte, K. L., \& Karabon, A. E. (2015). The power of improvisational teaching. Teaching and Teacher Education, 48, 1321. https://doi.org/10.1016/j.tate.2015.01.014

Gropen, J., Kook, J. F., Hoisington, C., \& Clark-Chiarelli, N. (2017). Foundations of science literacy: Efficacy of a preschool professional development program in science on classroom instruction, teachers' pedagogical content knowledge, and children's observations and predictions. Early Education and Development, 28(5), 607-631. https://doi.org/10.1080/10409289.2017.1279527

Grossman, P. L. (1990). The making of a teacher: Teacher knowledge and teacher education. Teachers College Press.

Gunn, A. A., Bennett, S. V., Alley, K. M., Barrera IV, E. S., Cantrell, S. C., Moore, L., \& Welsh, J. L. (2021). Revisiting culturally responsive teaching practices for early childhood preservice teachers. Journal of Early Childhood Teacher Education, 42(3), 265-280. https://doi.org/10.1080/10901027.2020.1735586

Hamel, E., Joo, Y., Hong, S. Y., \& Burton, A. (2021). Teacher questioning practices in early childhood science activities. Early Childhood Education Journal, 49, 375-384. https://doi.org/10.1007/s10643-020-01075-z

Hand, B., Park, S., \& Suh, J. K. (2018). Examining teachers' shifting epistemic orientations in improving students' scientific literacy through adoption of the Science Writing Heuristic approach. In K. S. Tang, \& K. Danielsson (Eds.), Global developments in literacy research for science education (pp. 339-355). Springer. https://doi.org/10.1007/978-3-319-69197-8_20

Hashweh, M. (2013). Pedagogical content knowledge: Twenty-five years later. In C. J. Craig, P. C. Meijer, \& J. Broeckmans (Eds.), From teacher thinking to teachers and teaching: The evolution of a research community (pp. 115-140). Emerald Group. https://doi.org/10.1108/S1479-3687(2013)0000019009

Hashweh, M. Z. (1996). Effects of science teachers' epistemological beliefs in teaching. Journal of Research in Science Teaching, 33(1), 47-63. https://doi.org/10.1002/(SICI)1098-2736(199601)33:1<47::AID-TEA3>3.0.CO;2-P

Hedges, H., \& Cullen, J. (2005). Subject knowledge in early childhood curriculum and pedagogy: Beliefs and practices. Contemporary Issues in Early Childhood, 6(1), 66-79. https://doi.org/10.2304/ciec.2005.6.1.10

Ho, H. N. J., \& Liang, J. C. (2015). The relationships among scientific epistemic beliefs, conceptions of learning science, and motivation of learning science: a study of Taiwan high school students. International Journal of Science Education, 37(16), 2688-2707. https://doi.org/10.1080/09500693.2015.1100346

Karabon, A. (2021). Examining how early childhood preservice teacher funds of knowledge shapes pedagogical decision making. Teaching and Teacher Education, 106, 103449. https://doi.org/10.1016/j.tate.2021.103449

Kind, V. (2009). Pedagogical content knowledge in science education: Perspectives and potential for progress. Studies in Science Education, 45(2), 169-204. https://doi.org/10.1080/03057260903142285

Kutluca, A. Y. (2021a). An investigation of elementary teachers' pedagogical content knowledge for socioscientific argumentation: The effect of a learning and teaching experience. Science Education, 105(4), 743-775. https://doi.org/10.1002/sce.21624

Kutluca, A. Y. (2021b). Investigation of the interactions among preschool teachers' components of pedagogical content knowledge for early science teaching. Southeast Asia Early Childhood Journal, 10(1), 117-137. https://doi.org/10.37134/saecj.vol10.1.10.2021

Kutluca, A. Y., \& Nacar, S. (2021). Exploring preschool teachers' pedagogical content knowledge: The effect of professional experience. Journal of Science Learning, 4(2), 160-172. https://doi.org/10.17509/jsl.v4i2.31599

Kutluca, A. Y., Soysal, Y., \& Radmard, S. (2018). Reliability and applied adaptation study of the epistemological belief scale towards learning. Journal of Theory and Practice in Education, 14(2), 129-152. https://doi.org/10.17244/eku.335287

Larimore, R. A. (2020). Preschool science education: A vision for the future. Early Childhood Education Journal, 48, 703-714. https://doi.org/10.1007/s10643-020-01033-9

Liang, J. C., \& Tsai, C. C. (2010). Relational analysis of college science-major students' epistemological beliefs toward science and conceptions of learning science. International Journal of Science Education, 32(17), 2273-2289. https://doi.org/10.1080/09500690903397796

Loughran, J., Mulhall, P., \& Berry, A. (2008). Exploring pedagogical content knowledge in science teacher education. International Journal of Science Education, 30(10), 1301-1320. https://doi.org/10.1080/09500690802187009

Magnusson, S., Krajcik, J., \& Borko, H. (1999). Nature, sources, and development of pedagogical content knowledge for science teaching. In J. Gess-Newsome, \& N. G. Lederman (Eds.), Examining pedagogical content knowledge (pp. 95-132). Springer. https://doi.org/10.1007/0-306-47217-1_4 
Mansour, N. (2013). Consistencies and inconsistencies between science teachers' beliefs and practices. International Journal of Science Education, 35(7), 1230-1275. https://doi.org/10.1080/09500693.2012.743196

McMillan, J. H., \& Schumacher, S. (2010). Research in education: Evidence based inquiry, my education lab series. Pearson.

Merino, C., Olivares, C., Navarro, A., Ávalos, K., \& Quiroga, M. (2014). Characterization of the beliefs of preschool teachers about sciences. Procedia-Social and Behavioral Sciences, 116, 4193-4198. https://doi.org/10.1016/j.sbspro.2014.01.915

Merriam, S. B., \& Tisdell, E. J. (2016). Qualitative research: A guide to design and implementation. John Wiley \& Sons.

Miles, M. B., \& Huberman, A. M. (1994). Qualitative data analysis: An expanded sourcebook. SAGE.

MoNE. (2013). Early childhood education program. Ministry of National Education. Ankara, Turkey.

Morgan, P. L., Farkas, G., Hillemeier, M. M., \& Maczuga, S. (2016). Science achievement gaps begin very early, persist, and are largely explained by modifiable factors. Educational Researcher, 45(1), 18-35. https://doi.org/10.3102/0013189X16633182

Morse, J. M. (1991). Approaches to qualitative-quantitative methodological triangulation. Nursing Research, 40(2), 120-123. https://doi.org/10.1097/00006199-199103000-00014

National Research Council. (2012). A framework for K-12 science education: Practices, crosscutting concepts, and core ideas. National Academies Press.

Nayfeld, I., Brenneman, K., \& Gelman, R. (2011). Science in the classroom: Finding a balance between autonomous exploration and teacher-led instruction in preschool settings. Early Education $\mathcal{E}$ Development, 22(6), 970-988. https://doi.org/10.1080/10409289.2010.507496

Neuman, S. B., \& Danielson, K. (2021). Enacting content-rich curriculum in early childhood: The role of teacher knowledge and pedagogy. Early Education and Development, 32(3), 443-458. https://doi.org/10.1080/10409289.2020.1753463

NGSS Lead States. (2013). Next generation science standards: For states, by states. The National Academy Press.

Nilsson, P. (2014). When teaching makes a difference: Developing science teachers' pedagogical content knowledge through learning study. International Journal of Science Education, 36(11), 1794-1814. https://doi.org/10.1080/09500693.2013.879621

Nilsson, P., \& Loughran, J. (2012). Exploring the development of pre-service science elementary teachers' pedagogical content knowledge. Journal of Science Teacher Education, 23(7), 699-721. https://doi.org/10.1007/s10972-011-9239-y

Nilsson, P. (2015). Catching the moments-Coteaching to stimulate science in the preschool context. Asia-Pacific Journal of Teacher Education, 43(4), 296-308. https://doi.org/10.1080/1359866X.2015.1060292

NSTA. (2014). NSTA position statement: Early childhood science education. Science and Children, 51(7), 10-12.

Oppermann, E., Brunner, M., \& Anders, Y. (2019). The interplay between preschool teachers' science self-efficacy beliefs, their teaching practices, and girls' and boys' early science motivation. Learning and Individual Differences, 70, 86-99. https://doi.org/10.1016/j.lindif.2019.01.006

Ozbey, S., \& Alisinanoglu, F. (2008). Identifying the general ideas, attitudes and expectations pertaining to science activities of the teachers employed in preschool education. Journal of Turkish Science Education, 5(2), 83-96.

Pajares, M. F. (1992). Teachers' beliefs and educational research: Cleaning up a messy construct. Review of Educational Research, 62(3), 307-332. https://doi.org/10.3102/00346543062003307

Palinkas, L. A., Horwitz, S. M., Green, C. A., Wisdom, J. P., Duan, N., \& Hoagwood, K. (2015). Purposeful sampling for qualitative data collection and analysis in mixed method implementation research. Administration and Policy in Mental Health and Mental Health Services Research, 42(5), 533-544. https://doi.org/10.1007/s10488-013-0528-y

Park, S. (2019). Reconciliation between the refined consensus model of PCK and extant PCK models for advancing PCK research in science. In A. Hume, R. Cooper, \& A. Borowski (Eds.), Repositioning pedagogical content knowledge in teachers' knowledge for teaching science (pp. 119-130). Springer. https://doi.org/10.1007/978-981-13-5898-2_4

Park, S., \& Chen, Y. C. (2012). Mapping out the integration of the components of pedagogical content knowledge (PCK): Examples from high school biology classrooms. Journal of Research in Science Teaching, 49(7), 922-941. https://doi.org/10.1002/tea.21022

Park, S., \& Oliver, J. S. (2008). Revisiting the conceptualisation of pedagogical content knowledge (PCK): PCK as a conceptual tool to understand teachers as professionals. Research in Science Education, 38(3), 261-284. https://doi.org/10.1007/s11165-0079049-6

Piasta, S. B., Pelatti, C. Y., \& Miller, H. L. (2014). Mathematics and science learning opportunities in preschool classrooms. Early Education and Development, 25(4), 445-468. https://doi.org/10.1080/10409289.2013.817753

Pierro, R. C. (2019). What leads to effective science-teaching practices in preschool classrooms? An examination of teachers' person, context, and time influences on science teaching [Doctoral dissertation, The University of North Carolina].

Prachagool, V., Nuangchalerm, P., Subramaniam, G., \& Dostál, J. (2016). Pedagogical decision making through the lens of teacher preparation program. Journal for the Education of Gifted Young Scientists, 4(1), 41-52. https://doi.org/10.17478/JEGYS.2016116351

Sackes, M. (2014). How often do early childhood teachers teach science concepts? Determinants of the frequency of science teaching in kindergarten. European Early Childhood Education Research Journal, 22(2), 169-184. https://doi.org/10.1080/1350293X.2012.704305 
Sackes, M., Flevares, L. M., \& Trundle, K. C. (2010). Four-to six-year-old children's conceptions of the mechanism of rainfall. Early Childhood Research Quarterly, 25(4), 536-546. https://doi.org/10.1016/j.ecresq.2010.01.001

Sackes, M., Flevares, L. M., Gonya, J., \& Trundle, K. C. (2012). Preservice early childhood teachers' sense of efficacy for integrating mathematics and science: Impact of a methods course. Journal of Early Childhood Teacher Education, 33(4), 349-364. https://doi.org/10.1080/10901027.2012.732666

Sackes, M., Trundle, K. C., \& Bell, R. L. (2013). Science learning experiences in kindergarten and children's growth in science performance in elementary grades. Education $\mathcal{E}$ Science, 38(167), 114-127.

Saglam, M., \& Aral, N. (2015). The study of determine pre-school teachers' ideas about science education. Inonu University Journal of the Faculty of Education, 16(3), 87-102. https://doi.org/10.17679/iuefd.16308213

Schommer, M. (1990). Effects of beliefs about the nature of knowledge on comprehension. Journal of Educational Psychology, 82(3), 498-504. https://doi.org/10.1037/0022-0663.82.3.498

Schommer-Aikins, M. (2004). Explaining the epistemological belief system: Introducing the embedded systemic model and coordinated research approach. Educational Psychologist, 39(1), 19-29. https://doi.org/10.1207/s15326985ep3901_3

Schraw, G., Bendixen, L. D., \& Dunkle, M. E. (2002). Development and validation of the epistemic belief Inventory (EBI). In B. Hofer, \& P. R. Pintrich (Eds.), Personal epistemology: The psychology of beliefs about knowledge and knowing (pp. 261-277). Lawrence Erlbaum.

Sengul, O., Enderle, P. J., \& Schwartz, R. S. (2020). Science teachers' use of argumentation instructional model: Linking PCK of argumentation, epistemological beliefs, and practice. International Journal of Science Education, 42(7), 1068-1086. https://doi.org/10.1080/09500693.2020.1748250

Shulman, L. S. (1986). Those who understand: Knowledge growth in teaching. Educational Researcher, 15(2), 4-14. https://doi.org/10.3102/0013189X015002004

Sing Chai, C., Teo, T., \& Beng Lee, C. (2009). The change in epistemological beliefs and beliefs about teaching and learning: A study among pre-service teachers. Asia-Pacific Journal of Teacher Education, 37(4), 351-362. https://doi.org/10.1080/13598660903250381

Smolkin L. B., \& Donovan C.A. (2015) Science and literacy: Considering the role of texts in early childhood science education. In: C. K. Trundle, \& M. Sackes (Eds.), Research in early childhood science education. Springer. https://doi.org/10.1007/978-94-0179505-0_10

Suh, J. K., \& Park, S. (2017). Exploring the relationship between pedagogical content knowledge (PCK) and sustainability of an innovative science teaching approach. Teaching and Teacher Education, 64, 246-259. https://doi.org/10.1016/j.tate.2017.01.021

Sundberg, B., \& Ottander, C. (2013). The conflict within the role: A longitudinal study of preschool student teachers' developing competence in and attitudes towards science teaching in relation to developing a professional role. Journal of Early Childhood Teacher Education, 34(1), 80-94. https://doi.org/10.1080/10901027.2013.758540

Tanase, M., \& Wang, J. (2010). Initial epistemological beliefs transformation in one teacher education classroom: Case study of four preservice teachers. Teaching and Teacher Education, 26(6), 1238-1248. https://doi.org/10.1016/j.tate.2010.02.009

Thomas, G. (2015). How to do your case study. SAGE.

Thulin, S., \& Redfors, A. (2017). Student preschool teachers' experiences of science and its role in preschool. Early Childhood Education Journal, 45(4), 509-520. https://doi.org/10.1007/s10643-016-0783-0

Toyama, N. (2016). Preschool teachers' explanations for hygiene habits and young children's biological awareness of contamination. Early Education and Development, 27(1), 38-53. https://doi.org/10.1080/10409289.2015.1036347

Trundle, K. C., \& Sackes, M. (2015). The inclusion of science in early childhood classrooms. In C. Trundle, \& M. Sackes (Eds.), Research in early childhood science education (pp. 1-6). Springer. https://doi.org/10.1007/978-94-017-9505-0_1

Tsai, C. C., Ho, H. N. J., Liang, J. C., \& Lin, H. M. (2011). Scientific epistemic beliefs, conceptions of learning science and selfefficacy of learning science among high school students. Learning and Instruction, 21(6), 757-769. https://doi.org/10.1016/j.learninstruc.2011.05.002

Ugras, M., \& Cil, E. (2018). Effect of nature of science activities on nature of science and scientific epistemological beliefs of preservice preschool teachers. The Eurasia Proceedings of Educational E Social Sciences, 4, 352-356.

Wilinski, B. (2017). Knowing and interpreting prekindergarten policy: A Bakhtinian analysis. Education Policy Analysis Archives, 25(27), 1-27. https://doi.org/10.14507/epaa.25.2211

Worth, K. (2010). Science in early childhood classrooms: Content and process. Early Childhood Research E Practice, 12(2), 1-17.

Wright, T. S., \& Gotwals, A. W. (2017). Supporting kindergartners' science talk in the context of an integrated science and disciplinary literacy curriculum. The Elementary School Journal, 117(3), 513-537. https://doi.org/10.1086/690273

Wu, D., Liao, T., Yang, W., \& Li, H. (2021). Exploring the relationships between scientific epistemic beliefs, science teaching beliefs and science-specific PCK among pre-service kindergarten teachers in China. Early Education and Development, 32(1), 82-97. https://doi.org/10.1080/10409289.2020.1771971 


\title{
APPENDIX A
}

\section{CRT Characteristics}

\section{Subject Area}

Big Idea(s)

Learning Outcomes

Scientific Process Skills

\author{
Questions
}

1. The purpose or orientation of the teacher to teach a particular subject

2. The orientation of the teacher about why the topic that the children want to learn is important

3. The orientation of the teacher on advanced and different knowledge bases that children should not learn yet

4. Teacher's orientation regarding the teaching process regarding difficulties, limitations and disabilities

5. The orientation of the teacher about child concepts that affect teaching on a particular subject

6. The orientation of the teacher on teaching approaches, strategies and techniques related to a particular subject

7. Strategies offered by the teacher to identify children's understanding and confusion about the topic taught

8. Teacher's orientation towards academic or non-academic teaching approaches and subject area knowledge resources 